\title{
Effects of fermentation on the nutritional status of Afzelia africana Sm. seed and its potentiality as aqua feedstuff

\author{
Suleiman, B.
}

Department of Biology, Faculty of Life Sciences, Ahmadu Bello University, Zaria, Nigeria

Abstract

Corresponding author: aquablends@gmail.com; +234 8184032454

The effects offermentation on proximate and anti-nutrient compositions of Afzelia africana seed were investigated. Two methods of fermentation were employed; the traditional fermentation (TF) and gut-filtrate treated fermentation (GFTF). Anti-nutrients tested for were; alkaloids, phytate, tannins, saponins and flavonoids. All proximate contents varied significantly $(P<0.05)$, except for ash. Afzelia africana fermented with cow gut filtrate poised the highest protein (19.35\%), ash (4.20\%) and lipid (32.13\%) contents. The effects of cow gut filtrate fermentation on the nutritional status of A. Africana seed was only apparently $(P>0.05)$ more pronounced than those of the natural fermentation. Fermentation significantly $(P<0.05)$ increased the proximate nutrients except for nitrogen free extracts; which it reduced significantly. Fermentation also increased all anti-nutrients composition of the seeds except for phytate content. Fermentation significantly $(P<0.05)$ enhanced crude protein by $30.45 \%$ for NF, 39.31\% for GFTF and crude lipid by $77.64 \%$ for TF and $99.56 \%$ for GTFT. Thus fermenting Afzelia africana seed for aquaculture purpose is advocated for owing to its ability to enhance crude protein and crude lipid, not forgetting its medicinal potential due to its enhanced phytochemical levels.

Keywords: Afzelia africana, Anti-nutrients, Fermentation, Proximate composition.

\section{Introduction}

Afzelia africana $\mathrm{Sm}$. belongs to the family Leguminosae and sub-family Caesalpinaceae (Keay et al., 1964 in: Ejikeme et al., 2010). It is called kawo, apa, akpalata and gayoki by the Hausa, Yoruba, Igbo and Fulani speaking areas of Nigeria, respectively. The seeds have waxy orange cup-like structure at their base and are used in Nigeria generally as soup thickening ingredient in much the same way as melon and Irvingia gabonensis seeds (Ejikeme et al., 2010). The plant is also used in local medicine for general pain relief and digestive problems (Adebayo and Ojo, 2013).

Protein-energy malnutrition is among the most serious problem tropical developing countries are facing. Legumes are increasingly being used as potential solution to this problem and that of low protein diet in highly populated region of the world (Ukhun and Ifehigh, 1988). Most of the edible legumes which could serve as sources of protein are however underutilized (Oshodi, 1992), and contain numerous toxic constituents of great variety. While some of these plants contain lethal toxins in high concentration and are unfit for consumption, others contain mildly toxic components in low doses and are benign (Macrae, 1993).

Food fermentation that raises the protein content or improve the balance of essential amino acids or their availability will have a direct curative effect. Similarly, fermentation processes that increase the content or availability of vitamins such as thiamine, riboflavin, niacin or folic acid can have profound direct effects on the health of the consumers of such foods (Steinkraus, 2002). Fermented foods generally have 


\section{Nutritional Quality of Fermented African Mahogany}

very good safety records even in the developing world where the foods are manufactured by people without training in microbiology or chemistry in unhygienic, contaminated environments (Steinkraus, 1997). In view of the overall nutrient and chemical composition, Afzelia africana seeds may be adopted as an inexpensive alternative protein source to alleviate protein malnutrition among traditional people living in developing countries. The aim of this study was therefore to assess the effect of two methods of fermentation on selected nutrient or nutrient-limiting chemical constituents of Afzelia africana seed.

\section{Materials and methods \\ Sample preparation}

The leaves and seeds of Afzelia africana were taken to the Herbarium in the Department of Botany, Ahmadu Bello University, Zaria, Nigeria, for identification. The seeds were air-dried, divided into three portions and put into separate polyethene bags. Two of the portions were fermented. Two methods of fermentation were employed; the traditional fermentation (TF) and gutfiltrate treated fermentation (GFTF). For the TF, $10 \mathrm{~kg}$ of the seed was ground into granules and wet with water (1lite of water to $10 \mathrm{~kg}$ seed) and bagged in duplicate packs of $5 \mathrm{~kg}$ inside white cellophane paper. They were then packed inside two different black polythene bags, tightly tied to exclude air for five days at room temperature to facilitate anaerobic fermentation. After which the fermented seeds were sun-dried for three days before milling (Apata et al., 1999). The GFTF followed a similar treatment as the TF.

One was fermented naturally and the other with cow gut-filtrate. The three samples were transported to the Food Science Laboratory, Institute of Agricultural
Research, Zaria, Nigeria, for analyses. The seeds were grounded to powdered flour before analysis.

Proximate analysis of Afzelia africana seed

Proximate analysis of Afzelia africana seed was determined in triplicates using recommended methods (AOAC, 2000). Samples were analysed for crude protein by the micro-Kjeldahl method of determining nitrogen and calculated as $\mathrm{N} \times 6.25$. Moisture content was determined by drying to a constant weight, crude lipid was determined as extracted ether using petroleum spirit or N-hexane within the soxhlet apparatus, crude fibre and ash contents were determined by incinerating dry samples in a Muffle furnace set at $550^{\circ} \mathrm{C}$. Carbohydrate was calculated as nitrogen free extracts by difference [100 $(\%$ crude protein $+\%$ lipid $+\%$ moisture + $\%$ crude fibre)].

\section{Determination of anti-nutrients of Afzelia} africana seeds

Alkaloids, Phytate, Tannins, Saponins and Flavonoids contents were determined using recommended methods of the Association of Official Analytical Chemist procedures (AOAC, 1990).

\section{Determination of alkaloids}

Two grams of the sample was weighed into a $250 \mathrm{~mL}$ beaker and $100 \mathrm{~mL}$ of $10 \%$ acetic acid in ethanol was added, covered and allowed to stand for $4 \mathrm{hrs}$. This was then filtered and filtrate was concentrated on a water bath to one quarter of the original volume. The entire/whole solution was allowed to settle. The precipitate was collected and washed with dilute ammonium hydroxide and then filtered. The residue was dried and weighed to show the alkaloid content as described by Harbone (1973).

\section{Determination of phytate content}

Phytic acid was determined using the method described by Wheeler and Ferrel 


\section{Suleiman}

(1971). $4 \mathrm{~g}$ of the sample was soaked in $100 \mathrm{ml}$ of $2 \% \mathrm{HCl}$ for $3 \mathrm{hrs}$ and then filtered. $25 \mathrm{ml}$ filtrate was dispensed into a conical flask and $5 \mathrm{ml}$ of $0.3 \mathrm{ml}$ ammonium thiocyanate solution was added as indicator. Thereafter, $53.5 \mathrm{ml}$ distilled water was added to the mixture to give it a proper acidity and this was titrated with standard iron III chloride solution, which contains about $0.00195 \mathrm{~g}(1.95 \mathrm{~g})$ of iron per millimeter until a brownish colour persisted for $5 \mathrm{~min}$.

\section{Determination of tannins}

Two grams of the sample was poured into a beaker containing $50 \mathrm{~mL}$ of distilled water and heated to $60^{\circ} \mathrm{C}$. Then it was filtered and the residue was discarded. $10 \mathrm{~mL}$ of $4 \%$ copper acetate solution was added to the hot filtrate and boiled for another 10min. The precipitate was filtered and the filtrate was discarded. The residue was dried using a filter paper and dried sample was then scraped from filter paper into a pre-weighed crucible. The weight was recorded as W. The crucible containing the sample was incinerated in a muffle furnace at $550^{\circ} \mathrm{C}$, then cooled in a desiccator and then reweighed as $\mathrm{W} 1$. The difference between the weight of sample before ashing and the ash residue after incineration represents the tannin content as described by Josyln (1970).

\section{Determination of saponin content}

Saponin content was determined using the AOAC (1990). Saponin extract was done using acetone and methanol. Crude lipid content of samples was extracted with acetone while methanol was used to extract saponin. Two grams of sample in triplicate were folded in filter paper and put in thimble and extracted by influxing in a Soxhlet extractor. Extraction was done with acetone in a $250 \mathrm{~cm}^{3}$ capacity round bottomed flask containing $100 \mathrm{~cm}^{3}$ methanol, fitted to the extractor and extraction sustained for another $3 \mathrm{hr}$. The weight of flask was taken before and after extraction to note the change in weight. Methanol was recovered by distillation after the second extraction and the flasks oven-dried and allowed to cool at room temperature and weighed. The saponin content was calculated using the formula;

$\operatorname{Saponin}(\mathrm{mg} / 100 \mathrm{~g})=$ $\underline{\mathrm{A}-\mathrm{B}} \times 100$

$\mathrm{Sm}$

Where $\mathrm{A}=$ mass of flask and extract

$\mathrm{B}=$ mass of empty flask

$\mathrm{Sm}=$ Sample mass

\section{Determination of flavonoids}

Flavonoids level was determined by gravimetric method described by Allen et al. (1974). 10g of sample was extracted with $100 \mathrm{ml}$ of $80 \%$ aqueous methanol at room temperature. It was filtered and the residue was transferred into a crucible for drying. This was dried at a constant weight in an oven. The percentage flavonoid was calculated as follows:

$\%$ Flavanoids $=$

Weight of dried residue $\times 100$

Weight of original sample

\section{Data analysis}

Data generated were statistically analyzed using means and standard deviation. Oneway ANOVA was adopted to test for significant difference $(\mathrm{P}<0.05)$ in the nutritional and anti-nutritional contents between the seeds of raw Afzelia africana, Afzelia africana seeds treated by natural fermentation (NF) and Afzelia africana seeds that were subjected to gut-filtrate treated fermentation (GFTF).

\section{Results and discussion}

The proximate composition of Afzelia africana seeds is shown in Table 1. Fermentation significantly $(\mathrm{P}<0.05)$ affected the proximate composition of the seeds, except for the ash content. The moisture, protein, lipid and fibre contents of the seeds increased significantly, while there was significant reduction in nitrogen free extracts content. 


\section{Nutritional Quality of Fermented African Mahogany}

Table 1: Proximate composition of raw and fermented Afzelia africana seed

\begin{tabular}{|c|c|c|c|c|c|c|}
\hline \multirow[b]{2}{*}{$\begin{array}{l}\text { Afzelia } \\
\text { africana } \\
\text { seed }\end{array}$} & \multicolumn{6}{|c|}{ Parameters } \\
\hline & $\%$ Moisture & $\%$ Ash & $\%$ Protein & \% Lipid & $\%$ Fibre & $\% \mathrm{NFE}$ \\
\hline Raw & $6.68 \pm 0.28^{c}$ & $4.13 \pm 0.08^{a}$ & $13.89 \pm 0.06^{\mathrm{b}}$ & $16.10 \pm 0.32^{c}$ & $4.57 \pm 0.02^{c}$ & $59.20 \pm 0.42^{\mathrm{a}}$ \\
\hline $\mathrm{NF}$ & $18.17 \pm 0.04^{\mathrm{a}}$ & $3.96 \pm 0.09^{\mathrm{a}}$ & $18.12 \pm 0.92^{\mathrm{a}}$ & $28.60 \pm 0.56^{\mathrm{b}}$ & $10.10 \pm 0.02^{\mathrm{a}}$ & $32.15 \pm 0.59^{b}$ \\
\hline GFTF & $14.93 \pm 0.10^{b}$ & $4.20 \pm 0.14^{\mathrm{a}}$ & $19.35 \pm 0.21^{\mathrm{a}}$ & $32.13 \pm 0.86^{\mathrm{a}}$ & $7.76 \pm 0.14^{\mathrm{b}}$ & $29.39 \pm 1.01^{\mathrm{c}}$ \\
\hline P Value & 0.000 & 0.348 & 0.001 & 0.000 & 0.000 & 0.000 \\
\hline
\end{tabular}

Means are presented. Means with the same superscript along columns do not vary significantly $(\mathrm{P}>0.05)$.

Note: TF - Traditional Fermentation, GFTF - Gut-filtrate Treated Fermentation

Natural fermentation (NF) effected a $30.45 \%$ increase in crude protein compared to the $39.31 \%$ increase in gut-filtrate treated fermentation (GFTF). A profound increase in lipid was observed in NF (77.64\%) and GFTF (99.56\%). Afzelia africana fermented with cow gut filtrate had the highest crude protein $(19.35 \%)$ and lipid $(32.13 \%)$ contents, while the naturally fermented seeds had the highest moisture $(18.17 \%)$ and fibre $(10.10 \%)$ contents. Raw A. africana had the highest nitrogen free extracts $(59.20 \%)$ content. The increase in moisture contents of the fermented seeds could be due to the treatment (soaking) it passed through during fermentation. This observation is in accordance with the reports of Ojokoh et al. (2015). The increases in crude protein content recorded with fermentation could be attributed to proteolytic activities of enzymes produced by microorganisms during fermentation (Amankwah et al., 2009). Soluble low molecular weight peptides and amino acids that contribute to flavour are produced through the enzymatic breakdown of proteins (Ouoba et al., 2003) as a result of fermentation. Bashir and Suleiman (2018) also reported significant increase of protein $(10.17 \%)$ and lipid $(46.62 \%)$ content of Tamarindus indica seed by fermentation. The significant increase in lipid content was reported to be caused by significant lipolysis of legumes by fermentation which yielded predominantly oleic, linoleic and linolenic acids which are essential fatty acids (Ouoba et al., 2003). Many animals cannot synthesize one or more of the fatty acids such as linoleic acid (18:2 $\omega-6)$ and must ingest them in plant-based foods (Smit, 2002).

There was significant increase in crude fibre contents which contradicts the reports of Igbabul et al. (2014) and Ojokoh et al. (2015), who reported fermentation to cause reduction in crude fibre contents of pearl millet and Acha. This implies that fermentation of Afzelia africana seed makes it a potential feedstuff for herbivorous and omnivorous tropical fish species such as tilapia, owing to increase in fibre content. Fermentation significantly $(\mathrm{P}<0.05)$ reduced the carbohydrate content. The reduction in carbohydrate content with fermentation could be attributed to utilization of fermentable sugars by lactic acid bacteria for growth and other metabolic activities (Ojokoh et al., 2013).

Table 2 presents the anti-nutrient composition of A. africana seeds. Fermentation significantly $(\mathrm{P}<0.05)$ increased alkaloid, tannin, saponin and flavonoid contents, and reduced phytate. The increase in some anti-nutrients could probably be associated with their formation during heat/alkaline processing (Gilani et al., 2005). The ability of anti-nutritional factors to pose health risks largely depends on their excretion viz-a-viz frequency of excretion. The NF seeds had the highest alkaloid $\left(3.68 \mathrm{mg} / \mathrm{g}^{-1}\right)$, tannin $\left(2.45 \mathrm{mg} / \mathrm{g}^{-1}\right)$ and saponin $\left(34.25 \mathrm{mg} / \mathrm{g}^{-1}\right)$ contents, while flavonoid content $\left(98.91 \mathrm{mg} / \mathrm{g}^{-1}\right)$ was more in the seeds subjected to GFTF. 


\section{Suleiman}

Table 2: Anti-nutrient composition of raw and fermented Afzelia africana seed

\begin{tabular}{lccccc} 
& & \multicolumn{3}{c}{ Parameters mg/g } \\
& Alkaloid & Phytate & Tannin & Saponin & Flavonoid \\
\hline Raw & $2.09 \pm 0.04^{\mathrm{b}}$ & $0.06 \pm 0.01^{\mathrm{a}}$ & $0.25 \pm 0.04^{\mathrm{c}}$ & $15.00 \pm 0.40^{\mathrm{b}}$ & $80.69 \pm 0.15^{\mathrm{c}}$ \\
NF & $3.68 \pm 0.18^{\mathrm{a}}$ & $0.06 \pm 0.00^{\mathrm{a}}$ & $2.45 \pm 0.02^{\mathrm{a}}$ & $34.25 \pm 0.15^{\mathrm{a}}$ & $96.56 \pm 0.02^{\mathrm{b}}$ \\
GFTF & $3.32 \pm 0.02^{\mathrm{a}}$ & $0.05 \pm 0.00^{\mathrm{a}}$ & $2.30 \pm 0.01^{\mathrm{b}}$ & $33.95 \pm 0.47^{\mathrm{a}}$ & $98.91 \pm 0.19^{\mathrm{a}}$ \\
P-Value & 0.004 & 0.535 & 0.000 & 0.000 & 0.000 \\
\hline Means are presented. Means with the same superscript along columns do not vary significantly $(\mathrm{P}>0.05)$.
\end{tabular}

Note: TF - Traditional Fermentation, GFTF - Gut-filtrate Treated Fermentation

The reduction in phytate content may be attributed to the activity of the endogenous phytase enzyme from the raw ingredient and inherent microorganisms which are capable of hydrolyzing the phytic acid in the fermented food preparations into inositol and orthophosphate (Sandberg and Andlid, 2002).

Tannins are secondary compounds of various chemical structures widely occurring in plants and interact with other anti-nutrients. Their anti-nutritional effects include interference with digestion by binding to proteins or minerals. Saponins on the other hand increase the digestibility of carbohydrate rich foods by detergentlike activity that reduces viscosity, preventing the normal obstructing action of such foods in the intestine (Kumar et al., 2012). Saponins have been reported to be highly toxic to fish when added to water (Kumar et al., 2012). However, the simultaneous consumption of saponin and tannin results in the loss of individual toxicity because the formation of tanninsaponin complexes inactivates the separate biological activity of both tannins and saponins (Kumar et al., 2012). Thus, the use of Afzelia africana seeds as aqua feedstuff can be explored.

The presence of flavonoids in A. africana also indicates that the seeds have biological functions such as anti-oxidant and antitumour properties (Okwu, 2004), which may be beneficial for tropical aquaculture candidates that require high energy for metabolic activities and invariably more feed, thus research into the use of relatively cheap non-conventional feedstuff is paramount. Flavonoids are polyphenolic compounds present in most plants. They are anti-oxidants that help protect cells from free radical damage which cause various health problems (Arthur, 1992). They help maintain healthy circulation, are antiinflammatory, anti-viral and they also strengthen capillaries (Verla et al., 2014).

\section{Conclusions}

Afzelia africana seed has high contents of protein, carbohydrate and lipids which suggest that it can serve as a good source of crude protein and energy for fish culture, coupled with the seed's medicinal potentials due to their high composition of phytochemicals; specifically flavanoids. Fermentation positively enhanced the proximate (lipid $>$ crude protein $>$ crude fibre) and beneficial anti-nutrients (notably flavonoids) composition of $A$. africana seeds. Thus inclusion of fermented $A$. africana seeds in fish feed formulations could enhance nutritional quality, digestibility and nutrient utilization at reduced production cost, and should be investigated.

\section{References}

Adebayo, S. F. and Ojo, O. C. 2013. Nutrient Compostion and Functional Properties of Afzelia Africana Seed. Journal of Environmental Science, Toxicology and Food Technology, 6(5): 1-3.

Allen, S. E. 1974. Chemical Analysis of 


\section{Nutritional Quality of Fermented African Mahogany}

Ecological Materials. Blackwell

Scientific Publications, London, UK. 565 pp.

A mankwah, E., Barimah, J., Acheampong, R., Addai, L. and Nnaji, C. 2009. Effect of fermentation and malting on the viscosity of maize-soyabean weaning blends. Pak. J. Nutr., 8:1671-1675: D o i : 10.3923/pjn.2009.1671.1675.

A.O.A.C. 1990. Official Methods of Analysis of the Association of Official Analytical chemists. 15th Edn. Washington D.C.

Apata, D. E., Joseph, J. K. and Adeoye, O. 1999. Performance blood Composition and carcass quality attributes of rabbit fed dietary levels of cassava and yam wastes. Nigerian Journal Pure and Applied Sciences, 14:786792.

Arthur, M. 1992. Literature Review of an Under-Utilized Legume, Canadian Glandiata I. Plant Source. Human Nutr., 55: 315 321.

Bashir, A. Y. and Suleiman, B. 2018. Growth and feed utilization value of fermented Tamarindus indica L. seed in the diet of Oreochromis niloticus (Linnaeus, 1758). Turkish Journal of Fisheries and Aquatic Sciences, 18, 905-911. Doi: 10.4194/1303-2712-v18 708.

Ejikeme, P. M., Obasi, L. $\overline{\mathbf{N}}$. and Egbuonu, A. C. C. 2010. Physico-chemical and toxicological studies on Afzelia africana seed and oil. African Journal of Biotechnology, 9(13), $1959-1963$ : D o i : 10.5897/AJB09.965.

Feed. 2014. Encyclopædia Britannica.
Encyclopadia Britannica Ultimate Reference Suite. Chicago: Encyclopædia Britannica.

Gilani, G. S., Cockell, K. A. and Sepehr, E. 2005. Effects of antinutritional factors on protein digestibility and amino acid availability in foods. Journal of AOAC Intl., 88(3): 967-987.

Harborne, J. B. 1973. Phytohemical Methods. Chapman and Hall, London, pp 110-113.

Igbabul, B. D., Amove, J. and Twadue, I. 2014. Effect of fermentation on the proximate composition, antinutritional factors and functional properties of cocoyam (Colocasia esculenta) flour. Afr. J. Food Sci. Technol., 5(3): 6774.

Joslyn, M. N. 1970. Methods in food analysis. New York Academic Press, pp. 49-61.

Keay, R. W. J., Onochie, C. F. A. and Stanfield, D. P. 1964. Nigerian Trees, National Press Ltd, Apapa, Publ. Fed. Dept. Forest Research. Ibadan, Nigeria. P. 47.

Kumar, V., Barman, D., Kumar, K., Kumar, V., Mandal, S. C. and Clercq, E. D. 2012. Antinutritional factors in plant feedstuffs used in aquafeeds. World Aquaculture, 64-68: $\mathrm{R}$ e $\mathrm{t} \mathrm{ri}$ e $\mathrm{ved}$ f $\mathrm{r}$ o $\mathrm{m}$ https://www.was.org/magazine/ ArticleContent.aspx?Id=845.

Macrae, R. 1993. Encyclopedia of Food Science and Nutrition. Harcourt Brace Joucenovich Publishers, London, England. 9: 4589.

Ojokoh, A. O., Daramola, M. K. and Oluoti, O. J. 2013. Effect of fermentation on nutrient and anti-nutrient composition of 


\section{Suleiman}

breadfruit (Treculia africana) and cowpea (Vigna unguiculata) blend flours. Afr. J. Agric. Res., 8, 3566-3570.

Ojokoh1, A. O., Fayemi1, O. E., Ocloo, F. C. K. and Nwokolo, E. I. 2015. Effect of fermentation on proximate composition, physicochemical and microbial characteristics of pearl millet (Pennisetum glaucum (L.) R. Br.) and Acha (Digitaria exilis (Kippist) Stapf) flour blends. Journal of Agricultural Biotechnology and Sustainable Development, 7(1), 1-8. Doi: 10.5897/JABSD2014.0236.

Okwu, D. E. 2004. Phytochemicals and vitamin content of indigenous spices of South Eastern Nigeria. Journal Sustainable Agriculture and Environment, 6: 30-34.

Oshodi, A. A. 1992. Proximate composition, nutritionally valuable minerals and functional properties of Adenopus breviflorus benth seed flour and protein concentrate. Food Chem., 45: 79-83.

Ouoba, L. I. I., Cantor, M. D., Diawara, B., Traore, A. S. and Jakobsen, M. 2003a. Degradation of African locust bean oil by Bacillus subtilis and Bacillus pumillus isolated from soumbala, a fermented African locust bean condiment. Journal of Applied Microbiology, 95: 868-873. Doi: 10.1046/j.13652672.2003.02063.x.

Ouoba, L. I. I., Rechinger, K. B., Barkholt, V., Diawara, B., Traore, A. S. and Jakobsen, M. 2003b. Degradation of proteins during the fermentation of African locust bean (Parkia biglobosa) by strains of Bacillus subtilis and Bacillus pumilus for production of Soumbala. Journal of Applied Microbiology, 94: 396-402. Doi: 10.1046/j.13652672.2003.01845.x.

Sandberg, A. S. and Andlid, T. 2002. Phytogenic and microbial phytases in human nutrition. Int. J. Food Sci. Technol., 37: 823833.

Smit, E. N. 2002. Essential fatty acid deficiency in malnourished children: erythrocyte and breastmilk fatty acid compositions in different populations Groningen: s.n. 58p.

Steinkraus, K. H. 1997. Classification of fermented foods: worldwide review of household fermentation techniques. Food Control, 8: 311-317.

Steinkraus, K. H. 2002. Fermentations in World Food Processing. Comprehensive Reviews in Food Science and Food Safety, 1: 2332.

Ukhun, M. E. and Ifehigh, E. O. 1988. Compositional Chemistry of Cassia alata seeds. Food Chem., $30205-210$.

Verla, A. W., Verla, E. N., Adowei, P., Brigg, A., Awa, E., Horsfall Jnr, M. and Spiff, A. I. 2014. Preliminary chemical profile of Telfairia occidentalis Hook. F. (Fluted pumpkin) seed shell. Merit Research Journal of Environmental Science and Toxicology, 2(4): 064-070.

Wheeler, E. L. and Ferrel, R. E. 1971. A Method for Phytic Acid Determination in Wheat and Wheat Fractions. Cereal Chemistry, 48: 312-320.

Received: $6^{\text {th }}$ November, 2018 Accepted: $9^{\text {th }}$ February, 2019 